\title{
STUDY OF THE ROLE OF ORAL CLONIDINE PREMEDICATION ON HAEMODYNAMIC CHANGES DURING LAPAROSCOPIC CHOLECYSTECTOMY UNDER GENERAL ANAESTHESIA WITH ENDOTRACHEAL INTUBATION
}

\author{
${ }^{1}$ Assistant Professor, Department of Anaesthesiology, North Bengal Medical College. \\ ${ }^{2}$ RMO-Cum-Clinical Tutor, Department of Anaesthesiology, North Bengal Medical College. \\ ${ }^{3}$ Assistant Professor, Mata Gujri Memorial MGM Medical College, Kishanganj, Bihar. \\ ${ }^{4}$ Consultant Anaesthesiologist, Siliguri, West Bengal. \\ ${ }^{5}$ Associate Professor, Department of Anaesthesiology, North Bengal Medical College. \\ 6 Professor, Department of Anaesthesiology, North Bengal Medical College.
}

Subhrajyoti Chattopadhyay', Richeek Kumar Pal2, Manasij Mitra ${ }^{3}$, Sumit Chakrabarti ${ }^{4}$, Mohanchandra Mandal5, Sekhar Ranjan Basu 6

\begin{abstract}
BACKGROUND

Laparoscopic cholecystectomy (LC) is known to produce Exaggerated Haemodynamic Responses (HDR) owing to pneumoperitoneum. Different pharmacological agents like opioids, benzodiazepines, lignocaine, beta blockers, nitroglycerine, etc. are being used to alleviate HDR. Clonidine at doses varying from 2 to 6 mcg per kg body weight or a fixed dose of 150 or $200 \mathrm{mcg}$ have been tested either through intravenous or oral routes with varying results thus creating confusion. Hence, we have designed to observe the effect of oral premedication with 200 mcg clonidine in attenuating HDR in patients undergoing LC under GA.
\end{abstract}

\section{METHODS}

Sixty adults aged between 18 and 60 years of either sex of American Society of Anaesthesiologists (ASA) physical status I or II, undergoing LC under GA were randomly allocated to receive orally either tablet clonidine $200 \mathrm{mcg}$ (Group 1, n=30) or multivitamin

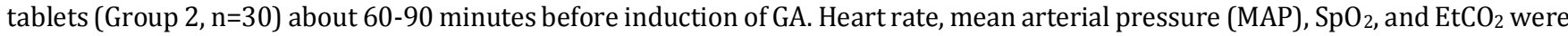
recorded at different perioperative time points. The level of sedation was also noted using Ramsay Sedation Scale. Postoperatively, the incidence of shivering was recorded.

\section{RESULTS}

The surge in heart rate and MAP after intubation, 15 and $30 \mathrm{~min}$ after pneumoperitoneum, after release of $\mathrm{CO}_{2}$, and after extubation were found lower in the study group $(\mathrm{p}=0.0001)$. Patients receiving oral clonidine premedication showed a deeper level of sedation before induction $(\mathrm{p}=0.001)$ and in the postoperative period $(\mathrm{p}<0.001)$, better control of postoperative shivering $(\mathrm{p}=0.038)$, nausea $(\mathrm{p}=0.038)$ and vomiting $(\mathrm{p}=0.036)$

\section{CONCLUSION}

Oral premedication with $200 \mathrm{mcg}$ clonidine is effective in achieving better perioperative haemodynamic stability, deeper level of sedation, and reduced incidences of postoperative shivering, nausea, and vomiting compared with placebo. With such dose, clonidine does not produce any harmful changes in observed parameters like $\mathrm{SpO}_{2}$, EtCO 2 , or ECG.

\section{KEYWORDS}

Adrenergic Alpha-Agonists, Cholecystectomy, Clonidine, Laparoscopy, Pain, Premedication.

HOW TO CITE THIS ARTICLE: Chattopadhyay S, Pal RK, Mitra M, et al. Study of the role of oral clonidine premedication on haemodynamic changes during laparoscopic cholecystectomy under general anaesthesia with endotracheal intubation. J. Evolution Med. Dent. Sci. 2016;5(54):3586-3591, DOI: 10.14260/jemds/2016/827

\section{INTRODUCTION}

Nowadays, laparoscopic cholecystectomy (LC) has virtually replaced conventional open cholecystectomy for symptomatic cholelithiasis and chronic cholecystitis. It is now considered the first option and has become the 'gold standard' in treating benign gallbladder disease. ${ }^{1}$ Several advantages such as earlier ambulation, minimal pain, early return to home, and quicker resuming to job have make LC so popular. Laryngoscopy and intubation are the essential parts of the anaesthetic care as most of these cases are performed under general anaesthesia

Financial or Other, Competing Interest: None.

Submission 14-06-2016, Peer Review 27-06-2016,

Acceptance 29-06-2016, Published 05-07-2016.

Corresponding Author:

Dr. Subhrajyoti Chattopadhyay,

C/o. Mr. Satyajit Chakroborty,

Trinayani Apartment (2 ${ }^{\text {nd }}$ Floor),

Taltala, Arabinda Pally,

Siliguri-734006, West Bengal.

E-mail:drsubhra1972@gmail.com

DOI: $10.14260 /$ jemds $/ 2016 / 827$
(GA). During airway manipulation (Laryngoscopy, intubation, and extubation), there is stimulation of sympathetic nervous system especially under light anaesthesia. ${ }^{2}$ Pneumoperitoneum itself and hypercarbia both stimulate the sympathetic nervous system and thereby increase blood pressure, heart rate, and the risk of arrhythmias. ${ }^{3}$

Different medications like opioids, benzodiazepines, lignocaine, beta blockers, calcium channel blockers, nitroglycerine, etc. are being used to alleviate these haemodynamic responses (HDR) and the choice is often influenced by the experience and preference of anaesthesia care provider and local availability. Clonidine, a centrallyacting alpha- 2 agonist, is an antihypertensive having sedative and analgesic properties, which have also been used to attenuate the HDR of laryngoscopy, intubation, pneumoperitoneum, and extubation. ${ }^{4}$ Co-induction with intravenous (IV) clonidine have already been proved in reducing postoperative nausea and vomiting (PONV) when compared with placebo. 5 In placebo-controlled trial, the 
efficacy of IV clonidine premedication has been investigated using various doses such as $2 \mathrm{mcg} / \mathrm{kg}$ versus (vs) $4 \mathrm{mcg} / \mathrm{kg} .{ }^{6}$, $2 \mathrm{mcg} / \mathrm{kg}$ vs $4 \mathrm{mcg} / \mathrm{kg}$ vs $6 \mathrm{mcg} / \mathrm{kg} .^{7}$ Intravenous clonidine ( $3 \mathrm{mcg} / \mathrm{kg}$ ) administered just prior to intubation has been compared with oral clonidine ( $4 \mathrm{mcg} / \mathrm{kg}$ ) given $90 \mathrm{~min}$ before induction where intravenous administration was found superior to oral clonidine and placebo for attenuation of stress response to intubation. ${ }^{2}$

Clonidine premedication using oral route has been investigated for attenuation of HDR (adrenergic response) of airway instrumentation and pneumoperitoneum. Different doses have been compared in several studies such as $100 \mathrm{mcg}$ vs $200 \mathrm{mcg} .{ }^{8}, 2 \mathrm{mcg} / \mathrm{kg}$ vs $4 \mathrm{mcg} / \mathrm{kg} .{ }^{9}$ and $2.5 \mathrm{mcg} / \mathrm{kg}$ vs 5 $\mathrm{mcg} / \mathrm{kg} .{ }^{10}$ Higher dose such as $6 \mathrm{mcg} / \mathrm{kg}$ has also been reported to be effective in improving circulatory stability and reducing anaesthetic requirement in hypertensive patients for major vascular surgery.11 Later, lower doses such as 150 mcg. ${ }^{3,12}$ or 200 mcg. ${ }^{13}$ has been found beneficial in reducing HDR and PONV. However, trials with contrast findings already exists stating that clonidine does not modify the overall HDR using dose $3 \mathrm{mcg} / \mathrm{kg}$ compared to oral diazepam $(0.2$ $\mathrm{mg} / \mathrm{kg}) \cdot{ }^{14}$ or hydroxyzine $(1 \mathrm{mg} / \mathrm{kg}) .{ }^{15}$

To the horizon of our knowledge, clonidine has extensively been evaluated for premedication via intravenous and oral routes using different doses. Researchers have observed the beneficial effects of clonidine at variable doses. This indicated that the quest is still on to determine the effective dose with acceptable adverse event profile especially for different population in different geographical area. Conflicts and contrast regarding optimum dose do exist among the existing plethora of published data even at the time of designing this study and thus have created a perplexed scenario. Hence, the present study was designed to observe the effect of clonidine as pre-anaesthetic medication at a dose of $200 \mathrm{mcg}$ via oral route in attenuating HDR in patients undergoing LC under GA. We hypothesized that oral premedication with clonidine 200 mcg would reduce the haemodynamic surges of intubation at various time points of pneumoperitoneum and that of extubation compared to placebo.

\section{MATERIALS AND METHODS}

The present study was carried out in a tertiary care hospital in West Bengal after obtaining approval from Institute's Ethics Committee. Sixty adult patients aged between 18 and 60 years of either sex conforming to American Society of Anaesthesiologists (ASA) physical status I or II undergoing GA for LC surgery were selected for this study after thorough preoperative evaluation. During this evaluation, patients were provided with all necessary information and made to understand that they can opt out even in the last moment at their will and after that written consent were received from all patients.

Patients with history of hypertension, ischaemic heart disease, valvular heart disease, left ventricular failure, or atrioventricular conduction defect were excluded from the study. Patients concomitantly taking any chronic medication such as antihypertensive, analgesics, antipsychotics or sedative-tranquilizers (Such as clonidine, methyldopa, beta blockers, benzodiazepines, MAO inhibitors, etc.), were also excluded from the study. Other exclusion criteria were known hypersensitivity to the study drug, participation in any other clinical trial within past 1 month, any other condition placing the subject at high risk or unfit for the trial.
A thorough pre-anaesthetic checkup was done. History of present medical condition, past illness, family history, drug history, history of allergy if any, history of operation and anaesthesia and related complication if any, personal history were taken in detail. Physical examination was carried out and patients were thoroughly examined for pallor, cyanosis, clubbing, oedema, neck glands enlargement, temperature, pulse rate, and non-invasive blood pressure (Both supine and standing), jaundice, jugular venous pressure, nutritional status. Their body weights were recorded. Systemic examination was carried out to rule out any significant cardiovascular, respiratory, gastrointestinal, genitourinary, and central nervous systems abnormality.

Formal examination of airway was done. Movements of head and cervical spine and the thyromental distance were assessed. Patients having either Mallampati grade I or II only were selected. Patients having any criteria of difficult airway were excluded from this study as difficult and prolonged laryngoscopy might interact with the actions of the drugs.

The preoperative investigations were performed and evaluated namely complete blood count including haemoglobin concentration, macroscopic and microscopic examination (RE/ME) of urine, fasting and postprandial blood sugar, serum urea and creatinine, 12-lead resting ECG and chest X-ray (PA view).

After preoperative checkup, patients who fulfilled the selection criteria for this study were explained about the anaesthetic procedure and premedication, its benefits and hazards. A written informed consent was taken from every patient before anaesthesia.

A total of sixty patients were randomly allocated to receive orally either tablet clonidine $200 \mathrm{mcg}$ (Group 1, n=30) or multivitamin tablets (Group 2, $\mathrm{n}=30$ ). To elaborate, Group 1 patients received 2 tablets of 100 mcg clonidine (Total 200 mcg) and group 2 patients received 2 multivitamin tablets about 60-90 minutes before induction of general anaesthesia. Randomization was done in the preoperative holding area (Special ward near OR) by revealing the sealed opaque envelope containing computer-generated randomization number.

In the morning of operation, the patients were reassessed. Baseline (Before premedication) pulse rate, non-invasive blood pressures (Mean arterial pressure), and $\mathrm{SpO}_{2}$ were noted. A peripheral venous line was setup in each patient. A standard anaesthetic sequence was followed in every patient. Anaesthesia machine, breathing systems, monitors, ventilators, suction apparatus, and laryngoscope were checked for proper functioning before starting the procedure. Pulse oximeter, non-invasive blood pressure cuff, and ECG leads were attached to the patients. An intravenous line was inserted and the pre-induction values (baseline) of heart rate, mean arterial blood pressure, $\mathrm{SpO}_{2}$, and arrhythmia if any were recorded. Before induction of anaesthesia, lactated Ringer's solution was infused at the rate of $10 \mathrm{~mL} / \mathrm{kg}$ body weight.

All patients were pre-oxygenated with $100 \%$ oxygen for 3 minutes through a face mask followed by injection fentanyl 1.5 $\mathrm{mcg} / \mathrm{kg}$ body weight. Patients were induced with thiopentone sodium ( $5 \mathrm{mg} / \mathrm{kg}$ ). Endotracheal intubation was facilitated with Atracurium besylate $(0.5 \mathrm{mg} / \mathrm{kg})$. Haemodynamic parameters, $\mathrm{SpO}_{2}$, and $\mathrm{EtCO}_{2}$ were recorded immediately after ET tube insertion. Anaesthesia was maintained with $66 \%$ 
nitrous oxide in oxygen, $0.5-1.5 \%$ Sevoflurane and additional doses of Atracurium besylate. The tidal volume and the ventilator frequency were adjusted and intermittent positive pressure ventilation (IPPV) was continued by mechanical ventilator. Intra-operative hydration was maintained with lactated Ringer's solution.

Pneumoperitoneum was created by insufflations with $\mathrm{CO}_{2}$ and the operation table was tilted about 15 degree in reverse Trendelenburg position. Intraoperative pressure was kept below $15 \mathrm{mmHg}$ throughout the surgical procedure. After completion of the surgical procedure, neuromuscular blockade was reversed with inj. neostigmine $0.05 \mathrm{mg} / \mathrm{kg} \mathrm{IV}$ along with inj. glycopyrrolate $0.01 \mathrm{mg} / \mathrm{kg}$ IV. Oropharyngeal suctioning was done. After the return of airway reflexes assessed clinically, extubation was carried out after deflating the cuff. Supplemental oxygen was given after extubation until stabilization of patients. Incidences of nausea, vomiting, and shivering in the postoperative period were recorded. The observer who took responsibility of observing data were kept unaware of group allocation.

All patients were monitored and haemodynamic parameters (Heart rate and mean arterial pressure), $\mathrm{SpO}_{2}$, and $\mathrm{EtCO}_{2}$ were recorded at different points of time namely, before induction, immediately after endotracheal intubation, before pneumoperitoneum, 15 and 30 minutes after pneumoperitoneum, after release of $\mathrm{CO}_{2}$, and after extubation. Postoperatively, the incidence of shivering was noted.

Sedation was assessed in every patient before premedication, before induction, and in immediate postoperative period using six points (1-6) Ramsay Sedation Scale ${ }^{16}$, which states that score 1 is 'anxious and agitated or restless, or both', score 2 is 'co-operative, oriented, and calm', score 3 is 'responsive to commands only', score 4 is 'exhibiting brisk response to light glabellar tap or loud auditory stimulus', score 5 is 'exhibiting sluggish response to light glabellar tap or loud auditory stimulus' and score 6 is 'unresponsive to light glabellar tap or loud noise'.

Results of different observations made in this study were analysed by using unpaired ' $\mathrm{t}$ ' test and 'Chi-square' test. The level of significance was determined by ' $\mathrm{P}$ ' value and $\mathrm{P}<0.05$ was considered as significant.

\section{RESULTS}

The study spanned from January, 2011 to April, 2012. No patient was lost to follow up. Hence data from sixty patients were available for analysis.

\begin{tabular}{|c|c|c|c|}
\hline Parameters & $\begin{array}{c}\text { Group 1 } \\
\text { (n=30) }\end{array}$ & $\begin{array}{c}\text { Group 2 } \\
\text { (n=30) }\end{array}$ & P value \\
\hline $\begin{array}{c}\text { Age } \\
\text { (years) }\end{array}$ & $35.2 \pm 11.02$ & $35.73 \pm 11.31$ & $\begin{array}{c}0.854 \\
(\mathrm{NS})\end{array}$ \\
\hline $\begin{array}{c}\text { Body Weight } \\
\text { (kgs) }\end{array}$ & $50.73 \pm 5.02$ & $50.83 \pm 5.17$ & $\begin{array}{c}0.940 \\
(\mathrm{NS})\end{array}$ \\
\hline M: F (n, \%) * & $13: 17$ & $12: 18(40.0 \%)$ & $\begin{array}{c}0.793 \\
(\mathrm{NS})\end{array}$ \\
\hline \multicolumn{3}{|c|}{ Data presented as mean \pm Std. Deviation, tested with unpaired t- } \\
test, except marked *, which is categorical data and tested using \\
Pearson's Chi Square Test. P<0.05 is considered as statistically \\
significant. \\
\hline \multicolumn{3}{|c|}{ Table 1: Demographic Profile } \\
\hline
\end{tabular}

The patients of both the groups were comparable regarding demographic profile.

\begin{tabular}{|c|c|c|c|}
\hline Parameter & $\begin{array}{c}\text { Group 1 } \\
\text { (n=30) }\end{array}$ & $\begin{array}{c}\text { Group 2 } \\
\text { (n=30) }\end{array}$ & P value \\
\hline Heart Rate (bpm) & Mean \pm SD & Mean \pm SD & \\
\hline $\begin{array}{c}\text { Before Premedication } \\
\text { (Baseline) }\end{array}$ & $90 \pm 5.4$ & $89.63 \pm 5.49$ & $\begin{array}{c}0.795 \\
(\mathrm{NS})\end{array}$ \\
\hline Before Induction & $78.43 \pm 4.87$ & $79.1 \pm 4.87$ & $\begin{array}{c}0.598 \\
(\mathrm{NS})\end{array}$ \\
\hline $\begin{array}{c}\text { Immediately after ET } \\
\text { Tube Insertion }\end{array}$ & $84.3 \pm 4.08$ & $90.43 \pm 7.01$ & $0.0001(\mathrm{~S})$ \\
\hline $\begin{array}{c}\text { Before } \\
\text { Pneumoperitoneum }\end{array}$ & $76.73 \pm 3.02$ & $79.23 \pm 4.15$ & $0.010(\mathrm{~S})$ \\
\hline $\begin{array}{c}\text { 15 mins after } \\
\text { Pneumoperitoneum }\end{array}$ & $79.43 \pm 2.81$ & $84.03 \pm 5.22$ & $0.0001(\mathrm{~S})$ \\
\hline $\begin{array}{c}\text { 30 mins after } \\
\text { Pneumoperitoneum }\end{array}$ & $80.93 \pm 2.7$ & $87.4 \pm 5.29$ & $0.0001(\mathrm{~S})$ \\
\hline After release of CO ${ }_{2}$ & $75.67 \pm 2.32$ & $79.9 \pm 4.21$ & $0.0001(\mathrm{~S})$ \\
\hline After Extubation & $84.63 \pm 3.73$ & $92.13 \pm 4.82$ & $0.0001(\mathrm{~S})$ \\
\hline $\begin{array}{c}\text { Data is presented as Mean } \pm \text { Standard Deviation, and tested with } \\
\text { unpaired t-test, NS-non significant; S- significant. P<0.05 is } \\
\text { significant; bpm= beats per min }\end{array}$ \\
\hline \multicolumn{4}{|c|}{$\begin{array}{c}\text { Table 2: Baseline and Variations in Heart Rate (BPM) in } \\
\text { Different Points of Time }\end{array}$} \\
\hline
\end{tabular}

Table 2 shows that the mean and standard deviation of baseline heart rate and the variations of heart rate before premedication and before induction in two groups were comparable. But, in other points of time, there was significant difference between two groups $(\mathrm{p}<0.05)$ and heart rate was higher in group 2 receiving placebo. In patients receiving clonidine (Group 1), heart rate was maximally controlled ( $p=0.0001$ ) just after intubation, and also $15 \mathrm{~min}, 30 \mathrm{~min}$ after pneumoperitoneum, after release of $\mathrm{CO}_{2}$ and after extubation. However, moderate control was noted before pneumoperitoneum in clonidine group $(\mathrm{p}=0.01)$.

\begin{tabular}{|c|c|c|c|}
\hline Parameter & $\begin{array}{c}\text { Group 1 } \\
(n=30)\end{array}$ & $\begin{array}{c}\text { Group } 2 \\
(n=30)\end{array}$ & $\begin{array}{c}P \\
\text { value }\end{array}$ \\
\hline MAP (mm Hg) & Mean \pm SD & Mean \pm SD & \\
\hline $\begin{array}{l}\text { Before Premedication } \\
\text { (Baseline) }\end{array}$ & $95.8 \pm 6.04$ & $94.9 \pm 6.29$ & $\begin{array}{c}0.574 \\
(\mathrm{NS})\end{array}$ \\
\hline Before Induction & $85.97 \pm 5.37$ & $87.23 \pm 5.82$ & $\begin{array}{c}0.385 \\
(\mathrm{NS})\end{array}$ \\
\hline $\begin{array}{l}\text { Immediately after ET } \\
\text { Tube Insertion }\end{array}$ & $94.47 \pm 5.9$ & $107.4 \pm 8.97$ & $\begin{array}{c}0.0001 \\
(S)\end{array}$ \\
\hline $\begin{array}{c}\text { Before } \\
\text { Pneumoperitoneum }\end{array}$ & $86.3 \pm 4.5$ & $91.17 \pm 5.73$ & $\begin{array}{c}0.001 \\
(S)\end{array}$ \\
\hline $\begin{array}{c}15 \text { mins after } \\
\text { Pneumoperitoneum }\end{array}$ & $89.9 \pm 4.23$ & $99.5 \pm 6.85$ & $\begin{array}{c}0.0001 \\
(S)\end{array}$ \\
\hline $\begin{array}{c}30 \text { mins after } \\
\text { Pneumoperitoneum }\end{array}$ & $92.7 \pm 4.25$ & $104.67 \pm 7.95$ & $\begin{array}{c}0.0001 \\
(S)\end{array}$ \\
\hline After release of $\mathrm{CO}_{2}$ & $86.93 \pm 3.96$ & $93.13 \pm 5.96$ & $\begin{array}{c}0.0001 \\
(S)\end{array}$ \\
\hline After Extubation & $97.87 \pm 6.1$ & $114.17 \pm 8.94$ & $\begin{array}{c}0.0001 \\
(S)\end{array}$ \\
\hline \multicolumn{4}{|c|}{$\begin{array}{c}\text { Data is presented as Mean } \pm \text { Standard Deviation, and tested with } \\
\text { unpaired t-test, NS-non significant; S-significant. } P<0.05 \text { is } \\
\text { significant; }\end{array}$} \\
\hline \multicolumn{4}{|c|}{$\begin{array}{c}\text { Table 3: Baseline and Variations in Mean Arterial Blood } \\
\text { Pressure (MAP) in Different Points of Time }\end{array}$} \\
\hline
\end{tabular}

Table-3 showed that there was no statistically significant difference of MAP values between two groups ( $p>0.05)$ before premedication and before induction. But, in other points of time, MAP was higher in Group-2. The difference between the two groups was found significant on analysis, $(p<0.05)$. 


\begin{tabular}{|c|c|c|c|}
\hline Parameter & $\begin{array}{c}\text { Group } 1 \\
(n=30)\end{array}$ & $\begin{array}{c}\text { Group } 2 \\
(n=30)\end{array}$ & $\begin{array}{c}\mathbf{P} \\
\text { value }\end{array}$ \\
\hline $\mathrm{SpO}_{2}(\mathrm{in} \%)$ & Mean \pm SD & Mean \pm SD & \\
\hline $\begin{array}{l}\text { Before } \\
\text { Premedication } \\
\text { (Baseline) }\end{array}$ & $98 \pm 1.17$ & $97.53 \pm 1.33$ & $\begin{array}{c}0.155 \\
\text { (NS) }\end{array}$ \\
\hline Before Induction & $98.67 \pm 0.84$ & $98.3 \pm 1.21$ & $\begin{array}{c}0.178 \\
\text { (NS) }\end{array}$ \\
\hline $\begin{array}{l}\text { Immediately after } \\
\text { ET Tube Insertion }\end{array}$ & $97.77 \pm 0.9$ & $97.8 \pm 1.06$ & $\begin{array}{l}0.896 \\
\text { (NS) }\end{array}$ \\
\hline $\begin{array}{c}\text { Before } \\
\text { Pneumoperitoneum }\end{array}$ & $97.9 \pm 0.84$ & $97.73 \pm 1.14$ & $\begin{array}{c}0.523 \\
\text { (NS) }\end{array}$ \\
\hline $\begin{array}{c}15 \text { mins after } \\
\text { Pneumoperitoneum }\end{array}$ & $97.43 \pm 0.82$ & $97.87 \pm 1.17$ & $\begin{array}{c}0.101 \\
(\mathrm{NS})\end{array}$ \\
\hline $\begin{array}{c}30 \text { mins after } \\
\text { Pneumoperitoneum }\end{array}$ & $97.57 \pm 1.1$ & $98.1 \pm 1.27$ & $\begin{array}{l}0.088 \\
\text { (NS) }\end{array}$ \\
\hline After release of $\mathrm{CO}_{2}$ & $97.9 \pm 0.84$ & $97.87 \pm 1.25$ & $\begin{array}{c}0.904 \\
\text { (NS) }\end{array}$ \\
\hline After Extubation & $97.67 \pm 0.99$ & $97.57 \pm 1.28$ & $\begin{array}{l}0.736 \\
\text { (NS) }\end{array}$ \\
\hline \multicolumn{4}{|c|}{$\begin{array}{l}\text { Data is presented as Mean } \pm \text { Standard Deviation, and tested } \\
\text { with unpaired t-test, NS-non significant; S-significant. } \\
\qquad \mathrm{P}<0.05 \text { is significant; }\end{array}$} \\
\hline $\begin{array}{r}\text { Table 4: Bc } \\
\text { in } L\end{array}$ & $\begin{array}{l}\text { e and Var } \\
\text { ent Points }\end{array}$ & $\begin{array}{l}\text { tions in } \mathrm{SpO}_{2} \\
\text { Time }\end{array}$ & \\
\hline
\end{tabular}

Table- 4 showed that there was no statistically significant difference of $\mathrm{SpO}_{2}$ values between two groups ( $\left.>0.05\right)$ in different points of time.

\begin{tabular}{|c|c|c|c|}
\hline Parameter & $\begin{array}{c}\text { Group } 1 \\
(n=30)\end{array}$ & $\begin{array}{c}\text { Group } 2 \\
(n=30)\end{array}$ & $\begin{array}{c}P \\
\text { value }\end{array}$ \\
\hline $\mathrm{EtCO}_{2}($ in $\mathrm{mm} \mathrm{Hg})$ & Mean \pm SD & Mean \pm SD & \\
\hline Before Induction & $28.77 \pm 0.9$ & $29 \pm 1.44$ & $\begin{array}{c}0.454 \\
\text { (NS) }\end{array}$ \\
\hline $\begin{array}{l}\text { Immediately after } \\
\text { ET Tube Insertion }\end{array}$ & $29 \pm 0.98$ & $29.37 \pm 1.47$ & $\begin{array}{c}0.261 \\
\text { (NS) }\end{array}$ \\
\hline $\begin{array}{c}\text { Before } \\
\text { Pneumoperitoneum }\end{array}$ & $28.83 \pm 0.75$ & $29.53 \pm 1.83$ & $\begin{array}{l}0.058 \\
\text { (NS) }\end{array}$ \\
\hline $\begin{array}{c}15 \text { mins after } \\
\text { Pneumoperitoneum }\end{array}$ & $30.47 \pm 0.73$ & $29.87 \pm 1.68$ & $\begin{array}{c}0.077 \\
\text { (NS) }\end{array}$ \\
\hline $\begin{array}{c}30 \text { mins after } \\
\text { Pneumoperitoneum }\end{array}$ & $30.57 \pm 1.22$ & $30.2 \pm 1.71$ & $\begin{array}{l}0.343 \\
\text { (NS) }\end{array}$ \\
\hline After release of $\mathrm{CO}_{2}$ & $29.3 \pm 1.02$ & $29.73 \pm 1.72$ & $\begin{array}{c}0.241 \\
\text { (NS) }\end{array}$ \\
\hline After Extubation & $30.27 \pm 1.01$ & $30.73 \pm 2.12$ & $\begin{array}{c}0.281 \\
\text { (NS) }\end{array}$ \\
\hline \multicolumn{4}{|c|}{$\begin{array}{l}\text { Data is presented as Mean } \pm \text { Standard Deviation, and tested } \\
\text { with unpaired t-test, } \mathrm{NS} \text {-non significant; S-significant. } \\
\mathrm{P}<0.05 \text { is significant; } \mathrm{EtCO}_{2} \text {, end-tidal carbon di-oxide } \\
\text { concentration. }\end{array}$} \\
\hline \multicolumn{4}{|c|}{ Table 5: $\mathrm{EtCO}_{2}$ in Different Points of Time } \\
\hline
\end{tabular}

Table- 5 showed that there was no statistically significant difference of $\mathrm{EtCO}_{2}$ values ( $\mathrm{p}>0.05$ ) between two groups in different points of time.

\begin{tabular}{|c|c|c|c|}
\hline Parameter & $\begin{array}{c}\text { Group 1 } \\
\text { (n=30) }\end{array}$ & $\begin{array}{c}\text { Group 2 } \\
\text { (n=30) }\end{array}$ & $\begin{array}{c}\text { P } \\
\text { value }\end{array}$ \\
\hline RSS scores & $\mathrm{n}(\%)$ & $\mathrm{n}(\%)$ & \\
\hline $\begin{array}{c}\text { RSS before } \\
\text { premedication }\end{array}$ & & & \\
\hline RSS-1 & $11(36.7 \%)$ & $10(33.3 \%)$ & $0.787(\mathrm{NS})$ \\
\hline RSS-2 & $19(63.3 \%)$ & $20(66.7 \%)$ & \\
\hline RSS before induction & & & \\
\hline RSS-1 & 0 & $9(30 \%)$ & $0.001(\mathrm{~S})$ \\
\hline RSS-2 & $30(100 \%)$ & $21(70 \%)$ & \\
\hline
\end{tabular}

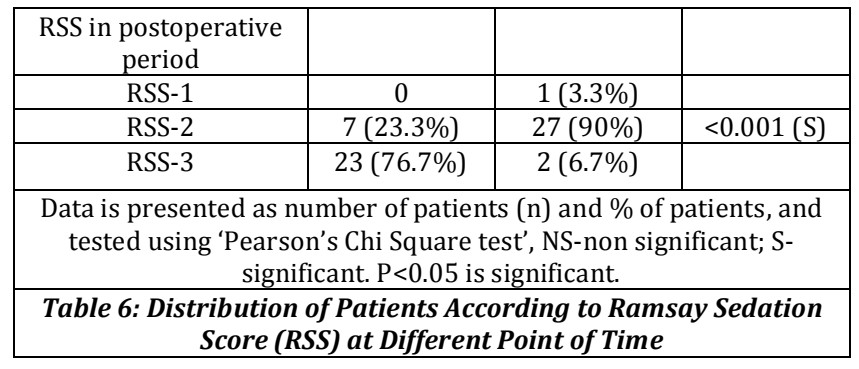

Table- 6 showed that before premedication, the sedation scores assessed using Ramsay sedation scale was comparable between the groups. Before induction, all patients in clonidine group achieved the level 2 sedation whereas only $70 \%$ patients reached that level in placebo group. In the postoperative period, almost $2 / 3^{\text {rd }}$ patients achieved level 3 sedation in clonidine group. In contrast, in the placebo group, only $6.7 \%$ reached level 3 sedation while the majority (90\%) patients remained in lighter level of sedation i.e., level 2). Significant difference regarding the sedation scores was found between the groups at the time before induction as well as in the postoperative period. Clearly, deeper level of sedation was observed in more number of patients in clonidine premedication group compared with placebo group.

\begin{tabular}{|c|c|c|c|}
\hline Parameter & $\begin{array}{c}\text { Group 1 } \\
\text { (n=30) }\end{array}$ & $\begin{array}{c}\text { Group 2 } \\
\text { (n=30) }\end{array}$ & P value \\
\hline $\begin{array}{c}\text { Shivering (Number of } \\
\text { incidences) }\end{array}$ & $\mathrm{n}(\%)$ & $\mathrm{n}(\%)$ & \\
\hline 0 & $29(96.7 \%)$ & $22(73.3 \%)$ & \\
\hline 1 & $1(3.3 \%)$ & $6(20.0 \%)$ & 0.038 \\
& & & \\
\hline 2 & 0 & $2(6.7 \%)$ & \\
\hline
\end{tabular}

Data is presented as number of patients (n) and \% of patients, and tested using 'Pearson's Chi Square test', NS-non significant; Ssignificant. $\mathrm{P}<0.05$ is significant.

Table 7: Distribution of Patients Experienced Shivering in the Postoperative Period

Table-7 showed that the occurrence of shivering was higher in Group-2. Altogether, 8 patients suffered shivering in the group receiving placebo while only 2 patients experienced that in patients receiving clonidine premedication. The difference in the incidences of shivering was found significant when analysed.

\begin{tabular}{|c|c|c|c|}
\hline Parameters & $\begin{array}{c}\text { Group 1 } \\
\text { (n=30) }\end{array}$ & $\begin{array}{c}\text { Group 2 } \\
\text { (n=30) }\end{array}$ & P value \\
\hline Nausea and Vomiting & $\mathrm{n}(\%)$ & $\mathrm{n}(\%)$ & \\
\hline $\begin{array}{c}\text { Nausea (Number of } \\
\text { incidences) }\end{array}$ & & & \\
\hline 0 & $28(93.3 \%)$ & $22(73.3 \%)$ & $\begin{array}{c}0.038 \\
(\mathrm{~S})\end{array}$ \\
\hline 1 & $2(6.7 \%)$ & $8(26.7 \%)$ & \\
\hline $\begin{array}{c}\text { Vomiting (Number of } \\
\text { incidences) }\end{array}$ & $30(100 \%)$ & $24(80 \%)$ & \\
\hline 0 & 0 & $4(13.3 \%)$ & 0.036 \\
\hline 1 & 0 & $2(6.7 \%)$ & \\
\hline 2 & & & \\
\hline
\end{tabular}

Data is presented as number of patients (n) and \% of patients, and tested using 'Pearson's Chi Square test', NS-non significant; Ssignificant. $\mathrm{P}<0.05$ is significant.

Table 8: Distribution of Patients Experienced Nausea and Vomiting in the Postoperative Period

Table-8 showed that in the postoperative period, 8 patients experienced nausea and 6 patients suffered vomiting in the placebo group (Group 2) while only 2 patients in 
clonidine group experienced nausea and none suffered vomiting.

\section{DISCUSSION}

Preoperative medication and preoperative psychological preparation are important aspects for anaesthetic management of patients. Selective approach to each patient has developed in place of routine administration of the same drugs to all patients. Premedication achieves relief from anxiety, induces sedation, analgesia, prevents autonomic stress responses, nausea and vomiting, shivering, reduces anaesthetic requirement, gastric fluid volume, and increases pH. ${ }^{17}$ Quest is still on for an ideal premedication agent fulfilling most of the goals without increasing adverse effects.

Clonidine, an $\alpha_{2}$ agonist, which has long been used as antihypertensive in medical practice is recently proved to have some beneficial premedication effects like sedation ${ }^{7}$, attenuation of laryngoscopic stress response ${ }^{2}$, prevention of PONV and shivering. ${ }^{3}$ In the present study, the effect of oral premedication with clonidine $200 \mathrm{mcg}$ was studied in respect of attenuation of HDR and other beneficial or adverse effects in comparison with multivitamin tablets as control drug.

The present study finds that using 200 mcg fixed dose of oral clonidine for all adult patients. A good attenuated haemodynamic stress response was obtained during intubation, pneumoperitoneum, and extubation. In the current study, a comparatively higher dose has been used $(200 \mathrm{mcg}$ clonidine in patients with mean body weight $50.73 \pm 5.02 \mathrm{kgs}$, average $\sim 4 \mathrm{mcg} / \mathrm{kg}$ ), which can be considered a reason for significant reduction of heart rate and mean arterial pressure at all-time points from just after intubation to post extubation.

Mikawa $\mathrm{K}$, et $\mathrm{al}^{6}$ compared the efficacy of two doses ( $2 \mathrm{mcg} / \mathrm{kg}$ vs $4 \mathrm{mcg} / \mathrm{kg}$ ) of oral clonidine as a premedicant in children undergoing elective ophthalmic surgery. They observed a dose-related sedation, but no clinically significant hypotension or bradycardia. They mentioned that combination of $4 \mathrm{mcg} / \mathrm{kg}$ oral clonidine and $0.03 \mathrm{mg} / \mathrm{kg}$ oral atropine can be an effective premedication for attenuation of increase in blood pressure and heart rate after tracheal intubation even in paediatric patient. ${ }^{6}$

Singh $\mathrm{S}$ and colleagues 18 found that premedication with oral clonidine $150 \mathrm{mcg}$ in laparoscopic cholecystectomy resulted in improved perioperative haemodynamics stability, and a reduction of intraoperative anaesthetic, and postoperative analgesic requirements. ${ }^{18-21}$ Oral clonidine premedication at a dose of $200 \mathrm{mcg}$ was found to attenuate the stress response to laryngoscopy and tracheal intubation and achieve better haemodynamic stability compared with placebo $^{22,23}$ and even superior to premedication using pregabalin at a dose of $150 \mathrm{mg} .{ }^{23}$ Oral premedication using clonidine $200 \mathrm{mcg}$ was found better than oral gabapentin (900 $\mathrm{mg}$ ) in attenuating the increase of blood pressure and heart rate. ${ }^{24}$

The present study also finds a reduction in the incidences of PONV and shivering in the postoperative period. Although, we observed it with the use of oral premedication using clonidine $200 \mathrm{mcg}$. Reports of previous study exists where authors achieved this with $150 \mathrm{mcg}$ of same drug orally. ${ }^{3}$

The present study concludes that premedication with 200 mcg oral clonidine administered 60-90 minutes before induction of anaesthesia is effective in achieving a better perioperative haemodynamics by reducing the surge in blood pressures and heart rate during different perioperative time points such as during laryngoscopy, intubation, pneumoperitoneum, and extubation compared with placebo. Patients receiving such dose of oral clonidine showed comparatively deeper level of sedation before induction as well as in the postoperative period and also reduced the incidences of postoperative shivering, nausea, and vomiting. Clonidine at a dose of $200 \mathrm{mcg}$ does not produce any harmful changes in observed parameters like $\mathrm{SpO}_{2}$, $\mathrm{EtCO}_{2}$, or ECG.

\section{REFERENCES}

1. Cawich SO, Mitchell DI, Newnham MS, et al. A comparison of open and laparoscopic cholecystectomy done by a surgeon in training. West Indian Med J 2006;55(2): 103-9.

2. Zalundaro MP, Zollinger A, Spahn DR, et al. Effects of intravenous and oral clonidine on hemodynamic and plasma catecholamine response to endotracheal intubation. J Clin Anesth 1997;9(2):143-7.

3. Das M, Ray M, Mukherjee G. Haemodynamic changes during laparoscopic cholecystectomy: effect of clonidine premedication. Indian J Anaesth 2007;51(3):205-10.

4. Wright PMC, Carabine UA, McClune S, et al. Preanaesthetic medication with clonidine. Br J Anaesth 1990;65(5):628-32.

5. Oddby-Muhrbeck E, Eksborg S, Bergendahl HT, et al. Effect of clonidine on postoperative nausea and vomiting in breast cancer surgery. Anesthesiology 2002;96(5): 1109-14.

6. Mikawa K, Maekawa N, Nishina K, et al. Attenuation of the catecholamine response to tracheal intubation with oral clonidine in children. Can J Anaesth 1995;42(10):869-74.

7. Kulka PJ, Tryba M, Zenz M. Dose response effects of intravenous clonidine on stress response during induction of graft patients. Anesth Analg 1995;80(2): 263-8.

8. Laurito CE, Baughman VL, Becker GL, et al. The effectiveness of oral clonidine as a sedative/anxiolytic and as a drug to blunt the hemodynamic responses to laryngoscopy. J Clin Anesth 1991;3(3):186-93.

9. Mikawa K, Maekawa N, Nishina K, et al. Efficiency of oral clonidine premedication in children. Anesthesiology 1993;79(5):926-31.

10. Handa F, Tanaka M, Nishikawa T, et al. Effects of oral clonidine premedication on side effects of ketamine anesthesia: a randomized, double-blind, placebocontrolled study. J Clin Anesth 2000;12(1):19-24.

11. Quintin L, Bouilloc X, Butin E, et al. Clonidine for major vascular surgery in hypertensive patients. A double blind, controlled, randomized study. Anesth Analg 1996;83(4):687-95.

12. Yu HP, Hseu SS, Yien HW, et al. Oral clonidine premedication preserves heart rate variability for patients undergoing laparoscopic cholecystectomy. Acta Anaesthesiol Scand 2003;47(2):185-90.

13. Javaherfroosh F, Pipelzadeh MR, Namazi M. Clonidine reduces postoperative nausea and vomiting in laparoscopic gynaecological surgery. Pak J Med Sci 2009;25(5):782-5.

14. Ramesh VJ, Bhardwaj N, Batra YK. Comparative study of oral clonidine and diazepam as premedicants in children. Int J Clin Pharmacol Ther 1997;35(5):218-21. 
15. Boussofara M, Bracco D, Ravussin P. Comparison of the effects of clonidine and hydroxyzine on haemodynamic and catecholamine reactions to microlaryngoscopy. Eur J Anaesthesiol 2001;18(2):75-8.

16. Stawicki SP. Sedation scales: very useful, very underused. OPUS 12 Scientist 2007;1(2):10-12.

17. Hata TM, Moyers JR. Preoperative patient assessment and management. In: Barash PG, Cullen BF, Stoelting RK, Cahalan M, (eds). Clinical anesthesia. $6^{\text {th }}$ ed. Philadelphia: Lippincott Williams and Wilkins 2009:573.

18. Singh S, Arora K. Effect of oral clonidine premedication on perioperative haemodynamic response and postoperative analgesic requirement for patients undergoing laparoscopic cholecystectomy. Indian J Anaesth 2011;55(1):26-30.

19. Chandrashekaraiah MM, Upadya M, Jayachandran SP, et al. Effects of clonidine premedication on haemodynamic changes during laparoscopic cholecystectomy-a randomized control study. Applied Cardiopulmonary Pathophysiology 2011;15:91-8.

20. Bhandari D, Tidke S, Sharma V, et al. Haemodynamic changes associated with laparoscopic cholecystectomy: effect of oral clonidine premedication. IOSR Journal of Pharmacy (IOSRPHR) 2012;2(4):72-7.
21. Singh R, Raghove $P$, Chawla $M$, et al. Effects of oral clonidine premedication on haemodynamic responses during laparoscopic cholecystectomy-a randomized control study. Indian Journal of Applied Research 2015;5(12):229-32.

22. Talebi H, Nourozi A, Fateh S, et al. Effect of oral clonidine premedication on haemodynamic response to laryngoscopy and tracheal intubation: a clinical trial. Pakistan Journal of Biological Sciences 2010;13(23):1146-50.

23. Gupta K, Sharma D, Gupta PK. Oral premedication with pregabalin or clonidine for haemodynamic stability during laryngoscopy and laparoscopic cholecystectomy: a comparative evaluation. Saudi J Anaesth 2011;5 (2): 179-84.

24. Shreedhara NS, Singh NR, Singh HS, et al. A comparative study of clonidine and gabapentin for attenuating haemodynamic responses to laryngoscopy and tracheal intubation. J Med Soc 2014;28(2):94-8. 